
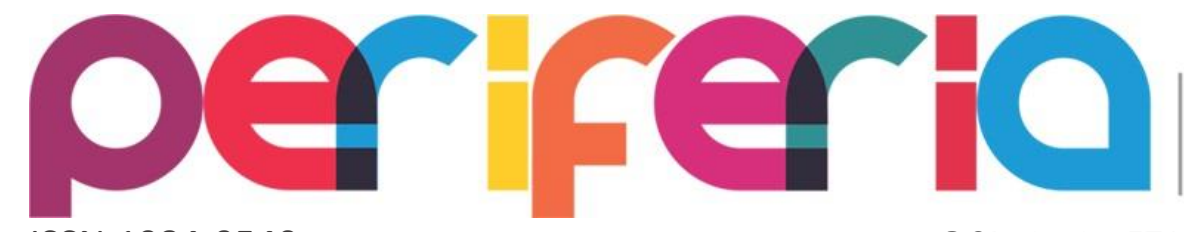

EDUCAÇÃO

CULTURA

\& COMUNICAÇÃO

ISSN:1984-9540

DOI: $10.12957 /$ periferia. 2021.55083

\title{
CONVERGÊNCIAS E DIVERGÊNCIAS ENTRE AS CONCEPÇÕES DE EDUCAÇÃO DO E NO CAMPO: algumas considerações
}

\author{
Waldiléia do Socorro Cardoso Pereira ${ }^{1}$ \\ Wansley Ferreira Freitas ${ }^{2}$
}

\section{Resumo}

A presente teorização é resultante de estudos realizados no curso de pós graduação em educação e tem como desafio refletir acerca da elaboração dos conceitos "Educação do Campo" e "Educação no Campo". O objetivo é destacar elementos que possam conduzir nossa reflexão no sentido de identificar possíveis divergências e convergências entre as duas concepções e como se constituem nos coletivos. Para entender esse movimento buscamos realizar leituras no arcabouço constituinte do movimento "Por uma Educação do Campo" também do "Grupo de Estudos e Pesquisa sobre Educação no Campo" ambos com robusta e sólida produção. Destaca-se a intencionalidade subjetiva/objetiva subentendida nas preposições "no" e "do" que antecedem a palavra "campo", que não nega o óbvio compromisso com a bandeira social/política por parte de ambos os coletivos. Apesar de algumas divergências, o mote central está na luta contra o sistema capitalista que inclui a persistência pela escolarização qualificada no campo. Esses campos, cerrados, várzeas, florestas e pantanais, esses rurais geograficamente tão diversos vão incorporando a materialidade de tantas gentes brasileiras e com isso os entendimentos são tão diversos quanto podem ser a própria subjetividade humana que cimenta o conhecimento que pode constituir os conceitos que ocupam espaço em sua representatividade.

Palavras-chave: Epistemologia da Educação. Educação no/do Campo. Políticas Educacionais.

\section{CONVERGENCES AND DIVERGENCIES BETWEEN THE EDUCATION CONCEPTS OF AND IN THE FIELD: some considerations}

\section{Abstract}

The current theorization is the result of studies carried out in the postgraduate course in education and its challengs is to reflect on the development of the concepts "education from the countryside" and "education in the countryside". The objetive is to highlith elements that can lead our reflections in order to

\footnotetext{
${ }^{1}$ Doutoranda em Educação. PPGE/UFSCar. Integrante GEPEC. Coordenação Comitê Estadual de Educação do Campo/AM Educação do Campo/SEMED/DEF/MAO. Professora FSDB/AM. Bolsista CAPES/FAPEAM AMAZONAS. Orcid https://orcid.org/0000-0002-6959-4818 e-mail: labanga_manaus@hotmail.com

${ }^{2}$ Doutorando em Educação. PPGE/UFSCar. Integrante GEPEC. Professor/SEMED/Aporé/GO. Orcid https://orcid.org/0000-0002-8173-6399 E-mail wansleyf@hotmail.com.
} 


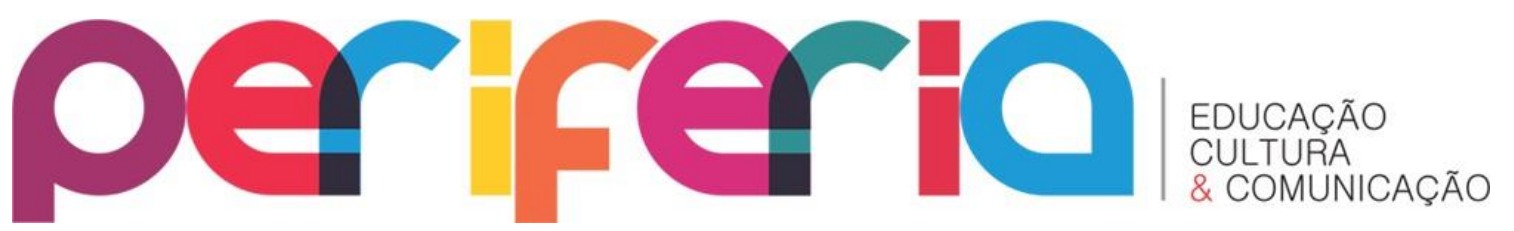

ISSN:1984-9540

DOI: $10.12957 /$ periferia.2021.55083

identify possible divergences and, primarily, convergences between the two conceptions and how they are constituted in colletives. To understand this movement, we seek reading in the framework of the "Movement For na Education in the Countryside" also from the "Group of Studies and Research on Education in the Countryside", both with robust and solid Productions. We highlith the subjective/objective intentionality implied when they use the word "from", or, "in" that precede the word "countryside" wich does not deny the obvious commitment to the social/ political banner by both colletives. Despite some divergences, the central thougth is the figth against the capitalist system, which includes the persistence for qualified schooling in the countryside. These fields, savanas, foodplains, forests and wetlands, these countrysides spaces, geographically so diverse, incorporate the materiality of so many brazilian people and with that the understandings are as diverse as can be the human subjectivity itself that grounds the knowledge that can constituted the concepts that occupy space in this representativeness.

Palavras-chave: Epistemology of Education. Education in/from the Countryside. Educational policies.

\section{CONVERGENCIAS Y DIVERGENCIAS ENTRE LAS CONCEPCIONES EDUCATIVAS Y EN EL CAMPO: algunas consideraciones}

\section{Resumen}

La presente teorización es el resultado de estúdios realizados en el posgrado em educación y su desafio es reflexionar sobre la elaboración de los conceptos "Educación de el ámbito rural" y "Educación en el ámbito rural”. El objetivo es destacar elementos que puedan guiar nuestra reflexión para identificar posibles divergências y, principalmente, convergências entre las dos concepciones y cómo se constituyen en los coletivos. Para entender este movimento, buscamos la lectura em el marco que constituyen el "Movimento Por Una Educación del Campo" también del "Grupo de Estudios e Investigaciones acerca de la Educación en el Campo" ambos com producción robusta y sólida. Destacamos la intencionalidade subjetiva/objetiva implícita em los monossílabos "de" y "en" que preceden a la palabra "campo", lo que no niega el compromisso evidente com la bandera social/política de ambos coletivos. A pesar de algunas divergencias, el lema central es la lucha contra el sistema capitalista, que incluye la perseverancia por la escolarización calificada em el campo. Estos campos, sabanas, llanuras aluviales, bosques y humedales, estas áreas rurales, geográficamente tan diversas, incorporan la materialidade de tantos brasileños y con eso los entendimentos son tan diversos como puede ser la subjetividade humana que cimenta los conocimientos que pueden constituir los conceptos que ocupan espacio en su representatividade.

Palabras-clave: Epistemología de la educación. Educación de/en el ámbito rural. Políticas educativas. 


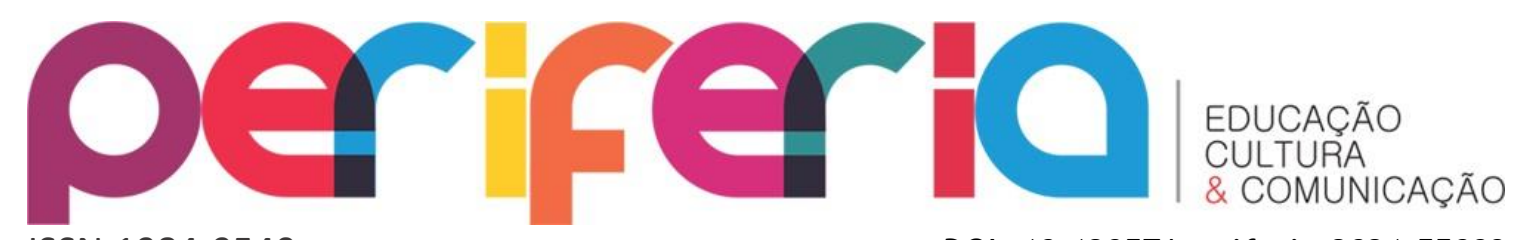

ISSN:1984-9540

DOI: $10.12957 /$ periferia. 2021.55083

Introdução

A libertação é um ato histórico, não um ato de pensamento, e é efetuada por relações históricas.

Karl Marx

A busca pela liberdade tem ocupado historicamente as ações humanas de diferentes maneiras, e, nessa perspectiva a educação se coloca como contribuinte nesse intento, no entanto, é importante o modo como conteúdos e formas serão trabalhados na escola seja ela no campo ou na cidade. Nesse sentido, refletindo sobre a Educação do/no Campo, pretendemos situar no presente texto elementos que apresentem possíveis divergências e convergências entre duas concepções que sustentam a defesa da educação na área rural.

Desse modo, as duas concepções a saber "Educação do Campo" cunhada pelo Movimento Por uma Educação do Campo e a concepção de "Educação no Campo" cunhada pelo Grupo de Estudos e Pesquisas sobre Educação no Campo, constituem o centro de nossa reflexão. Entendendo que mesmo entre controvérsias essencialmente os coletivos posicionam-se contra o sistema capitalista e contra qualquer processo que usurpe os direitos alcançados pelas populações residentes em áreas rurais. Ao apresentar tais questões pretendemos ampliar a discussão e o próprio entendimento sobre tais concepções sem negar os inevitáveis limites concernentes aos processos de construção do conhecimento.

Nossa intencionalidade é clarificar entre as linhas identitárias algumas aproximações, óbvio, sem ousar criar generalizações conclusivas acerca dos coletivos e de suas premissas. Na verdade, tratando-se de conceitos ainda em construção é certo que precisamos ter cautela diante de severos riscos relativos às afirmações que não devem ser consideradas absolutas. Todavia, enquanto movimento envolvente diante dessa totalidade nos dispomos discutir o tema para alcançar alguns de seus determinantes, compreendendo que as ponderações podem clarificar dúvidas existentes e ainda situar aspectos talvez velados acerca do assunto discutido.

Pensando conforme Konder (2008), observar certa realidade significa que: 


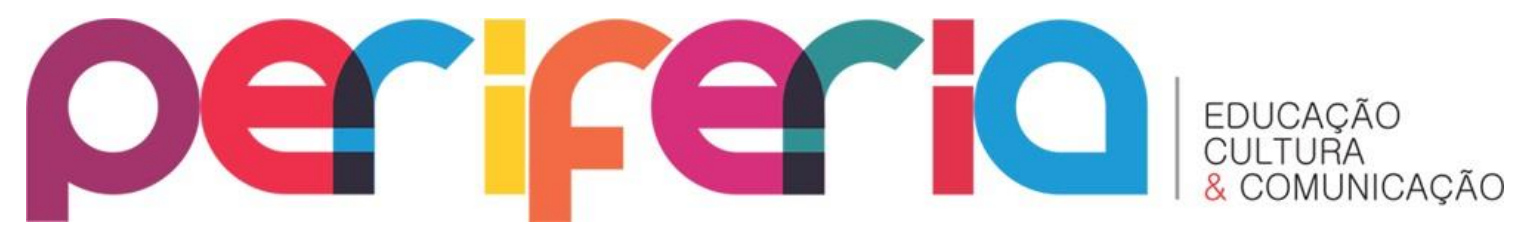

ISSN:1984-9540

DOI: $10.12957 /$ periferia.2021.55083

A visão de conjunto - ressalva-se - é sempre provisória e nunca pode pretender esgotar a realidade a que ele se refere. A realidade é sempre mais rica do que o conhecimento que temos dela. Há sempre algo que escapa às nossas sínteses; isso, porém, não nos dispensa do esforço de elaborar sínteses, se quisermos entender melhor nossa realidade. A síntese é a visão de conjunto que permite ao homem descobrir a estrutura significativa da realidade com que se defronta, numa situação dada. E é essa estrutura significativa - que a visão de conjunto proporciona - que é chamada totalidade (KONDER, 2008, p. 36).

Para alcançar essa visão de conjunto sobre o fato mesmo considerando a temporariedade provisória, tomamos como mediação aspectos da historiografia da própria educação na área rural brasileira. Inicialmente pontuamos aspectos acerca do ruralismo pedagógico conforme Bezerra Neto (2017) e Ribeiro (2012) em seguida as lutas empreendidas para pautar uma outra visão de escolarização na área rural liderada então pelo "Movimento Por Uma Educação do Campo" conforme Caldart (2012) Molina (2004) entre outros. Também pontuamos a defesa do "Grupo de Estudos e Pesquisas sobre Educação no Campo" conforme Bezerra Neto (1999, 2010, 2017), Basso (2017), Santos (2017) e Saviani (2013).

Cabe ressaltar a somatória nessa escrita de nossas subjetivações derivadas de estudos sobre escolarização no/do campo, águas e florestas na Amazônia, assim como, a atuação profissional e pesquisa acadêmica dos autores. Entendemos que todo esse quadro situa a produção como amalgama de pensamentos e realidades em que a primeira instigação se faz no uso dos monossílabos "no" e “do" que antecedem a palavra "campo". É preciso notar que eles não apenas interligam a palavra “educação” com a palavra “campo”, mas, mas expressam certos significativos e significantes, percepções objetivas e subjetivas que compõe o arcabouço dos grupos citados.

É inegável em cada perspectiva conceitual os argumentos e realizações intencionais dos dois coletivos. Nota-se que os argumentos emergem tanto da experiência acadêmica quanto da articulação com os movimentos sociais, e, é nessa relação que se constroem as críticas materializadas na resistência contra as opressões políticas e sociais. A priori, reside na concepção materialista da história que fundamenta ambos o levante da mesma bandeira de luta. Essa 


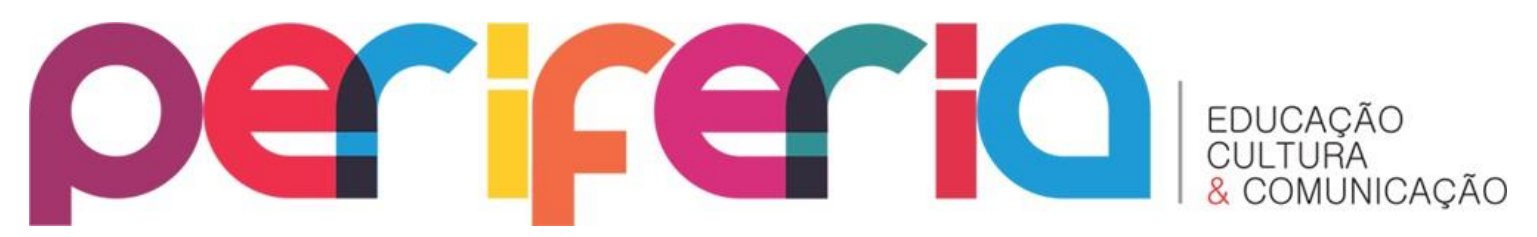

ISSN:1984-9540

DOI: $10.12957 /$ periferia. 2021.55083

identidade laboriosa funda seus referenciais justificativos pró liberdade das opressões advindas do capital na área rural.

Historiografias presentes: do movimento por uma educação do campo ao pacto de defesa da educação revolucionária no campo

Este é o nosso país

Esta é a nossa bandeira

É por amor a esta Pátria-Brasil

Que a gente segue em fileira.

José Pinto de Lima

O recorte do poema acima citado, de autoria de José Pinto de Lima, integrante do Movimento dos Trabalhadores Sem Terra, foi entoado por muitos militantes com pés no chão durante os anos 1980 e 1990, de mãos dadas, e, muitos anseios, febris, muitos trabalhadores do campo seguiram em marcha empunhando o desejo comum de liberdade das opressões cingidas pelo poder do sistema capital no campo.

A real historiografia da educação brasileira que se propõe narrar os fatos em sua concretude (SCHAFF, 1995), precisa ressaltar em sua narrativa a palavra resistência e trabalho, onde, se entrelaçam as vidas dos sujeitos. A resistência constituí a persistência dos trabalhadores vendo no trabalho a educação do/no campo. A labuta diária contra a espoliação, o estigma do atrasado, do caipira rasgado, sem terras, sem ser gentes, moldura o tempo passado e presente com negações arbitrárias. Segundo José Paulo Neto na afirmação sobre a natureza do ser e sua relação com o trabalho, que é seu ser no mundo concreto e espiritual, (2015, p. 61) "eis aí o ponto arquemédico da concepção filosófico-antropológica de Marx: a emergência do ser do homem pela via da sua atividade vital, o processo da auto constituição (autoprodução) do homem mediante o trabalho", ou seja, o ser humano se faz no trabalho.

A historiografia educacional advinda de estudos acadêmicos traz aspectos da luta dos oprimidos, do levante corajoso dos sujeitos, dos lavradores, dos campesinos, dos pescadores, das margaridas, dos chicos mendes, dos indígenas, quilombolas, daqueles que sacrificam suas vidas pela educação. São povos desgarrados da terra que na poetização do concreto feita por Chico Buarque 


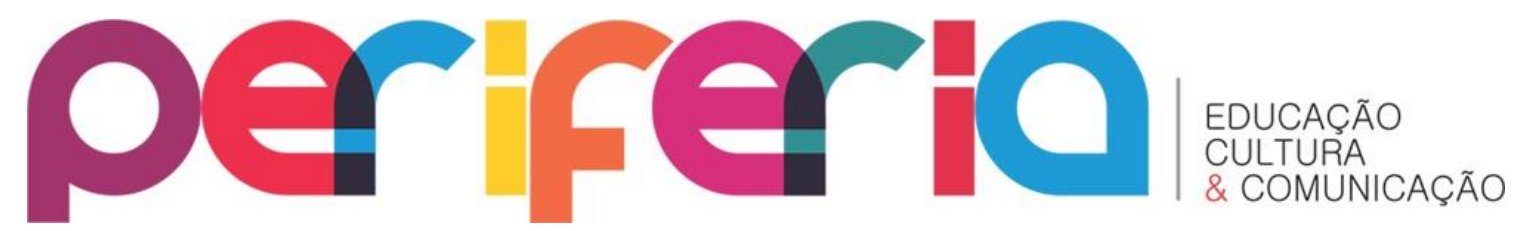

ISSN:1984-9540

DOI: $10.12957 /$ periferia.2021.55083

questiona "como então? Desgarrados da terra? Como assim?" os "Sem Terra", desse modo indagam-se os burgueses, como esses sujeitos pobres, residentes nos rios, barrancas, várzeas, campos, serrados, alagados, tantos trabalhadores, como ousam insurgir-se, unir e ousar, hastear sua bandeira de luta. Como ousam eles se organizarem em classe? Como ousam ir na frente de ação? ir em busca do que é seu, do que está sendo tomado pelo capital? (CALDART 2012, p.27).

Segundo Fernandes (2012), o Movimento dos Trabalhadores Rurais Sem Terra apresenta características sócio territorial porque reúne diversas categorias de sujeitos na resistência contra a espoliação e negação de direitos básicos para existência. Esses sujeitos se organizam enquanto classe e articulados hasteiam sua bandeira para fazer outra história, lutam pelo direito à terra, pela escolarização nas comunidades, pelo direito a realização de seus projetos de vida coletivizados em busca de outra sociedade mais justa. Para Arroyo significa:

Um dos princípios que orienta a Educação do Campo é que os seres humanos se fazem, se formam e se humanizam no fazer a história. Consequentemente, a diversidade de formas de fazer a história e o fato de os seres humanos serem reconhecidos como sujeitos de história ou serem segregados da nossa história imprime determinadas marcas no fazer-se, no formar-se, no humanizar-se que exigem reconhecimento na teoria e nos projetos de formação (ARROYO, 2012, p. 232).

Diante do desenvolvimento capitalista muitas etapas de superação são necessárias para que a organização e empoderamento da classe explorada possa ser realidade. Para Marx e Engels (2014) significa que "o proletariado atravessa diversos estágios em seu desenvolvimento, sua luta contra a burguesia começa com sua própria existência. No início, luta de trabalhadores isolados, depois os trabalhadores de um ramo da indústria de um lugar contra o burguês que os explora diretamente" (MARX e ENGELS, 2014, p. 118).

Frente a essa concretude material e existencial o "campo" não é apenas um substantivo comum em um texto, tem sim um contexto, o "campo" não cabe na objetivação romantizada e idealizada pelos que nele não vivem, em certas especulações paradisíacas como diz a letra da música de Jose Rodrigues Trindade e Luiz Otavio de Melo Carvalho (1972) gravada por Elis Regina "eu quero uma 


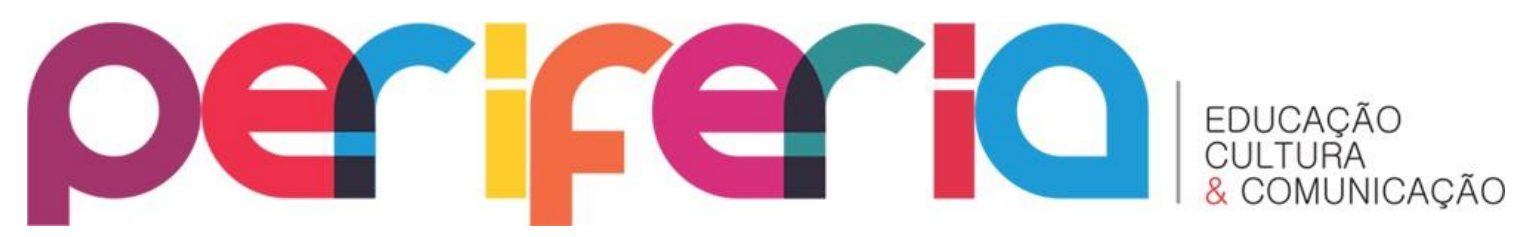

ISSN:1984-9540

DOI: 10.12957/periferia.2021.55083

casa no campo onde eu possa ficar no tamanho da paz [...] eu quero carneiros e cabras pastando solenes [...]" esse campo poetizado não é o concreto rural para a população pobre trabalhadora rural, para eles o campo é um espaço de disputa, de luta por direitos, a poesia apresenta o estereótipo do campo vivenciado pela classe burguesa que utiliza o campo para seu desfrute, e, ou, enriquecimento.

$\mathrm{Na}$ realidade, toda existência de vivências rurais diversificadas em biomas geográficos diversos em nosso país continental, os territórios rurais e nisso a territorialidade, são ambos compostos por elementos que engendram nos sujeitos, nos trabalhadores, mesmo vivendo em espaços geográficos variados, certa unidade de classe forjada na luta diária pela sobrevivência. A classe trabalhadora que vive no/do/para o campo, tendo nesse seu lugar originário, resistência na unidade assumida pela quebra dos grilhões impostos no pacto econômico espoliador. O lema secular, segundo, Marx e Engels (2014, p. 43) “não pode ser livre um povo que oprime o outro" impulsiona o movimento de resistência.

O empenho na construção do conceito identitário expressa sua resistência advinda das lutas na área rural. A educação realizada no campo sendo imposta pelo Estado como modalidade é invisibilizada enquanto direito aos trabalhadores do acesso a qualidade do ensino. O esforço nessa construção epistêmica incorpora a força constitutiva de embates porque lança ao Estado uma cobrança constitucional.

A conceituação torna o Estado responsável pelo impacto negativo que ele causa aos sujeitos do campo por possível negação de acesso aos seus direitos. Tomamos a fala de Engels "quando um indivíduo causa a outro um dano físico de tamanha gravidade que lhe causa a morte, chamamos esse ato de homicídio se o autor sabe de antemão, que o dano será mortal, sua ação se designa por assassinato" (ENGELS, p. 136) assim, pode-se considerar que ao permitir a condição desumana de exploração dos trabalhadores, seja no campo ou na cidade, considerando ser a miséria um fato cabível, é ela (sociedade/Estado) responsável por seus meandros. Segundo Engels: 


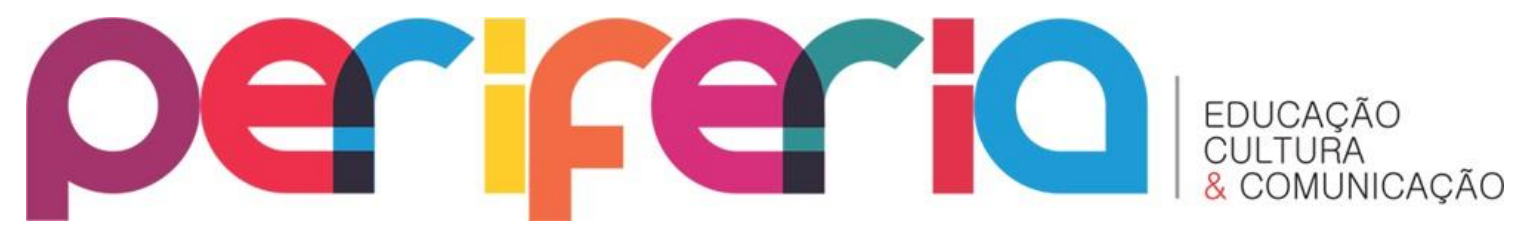

ISSN:1984-9540

DOI: $10.12957 /$ periferia. 2021.55083

Quando a sociedade põe centenas de proletários numa situação tal que ficam obrigatoriamente expostos à morte prematura, antinatural, morte tão violenta quanto a provocada por uma espada ou um projétil; quando ela priva milhares de indivíduos do necessário à existência, pondo-os numa situação em que thes é impossível subsistir; quando ela os constrange, pela força da lei, a permanecer nessa situação até que a morte (sua consequência inevitável) sobrevenha; quando ela sabe, e está farta de saber, que os indivíduos haverão de sucumbir nessa situação e, apesar disso, a mantém, então o que ela comete é assassinato. (ENGELS, 2014, p. 136-137).

Para avançar no debate contra essa situação a educação do/no campo se insere no contraponto aos modelos baseados nos meios de produção capitalista. Para Mészáros significa que "a produção é também uma forma de consumo social no curso da qual o homem é consumido como simples indivíduo e reproduzido como indivíduo social, com todos os poderes que lhe permitem empenhar-se numa forma humana de produção e consumo" (MÉZÁROS, 2006, p. 187). No bojo do desenvolvimento da economia brasileira cujas características agrárias e de monoculturas eram e ainda são latentes, a educação segue envolta no ideário da classe dominante.

Para Bezerra Neto (2017) e Ribeiro (2012) nesse processo, o denominado “ruralismo pedagógico" ocorre para sistematizar a formação no ambiente acirrado de mudanças políticas e econômicas. Tal modelo tinha e ainda tem sua intencionalidade no lucro do capital e suas oligarquias, portanto, fazia-se necessário manter os trabalhadores do campo no campo, ampliar a produção agrícola e, a escola seria então meio para galgar essa meta via ruralismo pedagógico:

O termo ruralismo pedagógico foi cunhado para definir uma proposta de educação do trabalhador rural que tinha como fundamento básico a ideia de fixação do homem no campo por meio da pedagogia. Ou seja, um grupo de intelectuais, pedagogos ou livres-pensadores defendiam que deveria haver uma pedagogia que ajudasse a fixar o homem no campo, ou que, pelo menos, dificultasse, quando não impedisse, sua saída desse habitat. (BEZERRA NETO, 2017, p.21).

Esse modelo educacional de fixação do trabalhador no campo encontra reações adversas no decorrer do tempo. Segundo Ribeiro: 


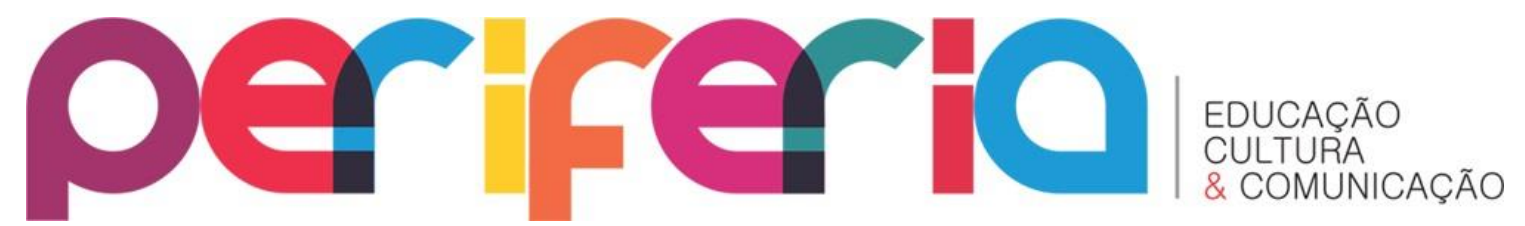

ISSN:1984-9540

DOI: $10.12957 /$ periferia. 2021.55083

A educação do campo projetada nesse processo coloca-se, então, como contraponto à existência de uma escola qualificada como "rural". Historicamente, a escola rural tem-se prestado a disseminar a civilidade e os valores relacionados ao trabalho e à vida urbanos, anulando, desta forma, os sujeitos que trabalham e vivem no campo, ou seja, os agricultores enquanto produtores de matérias primas, de conhecimentos, linguagens, culturas e artes. Conhecedores desta realidade, educadores/as e pesquisadores/as sensíveis a esta demanda buscam formular um projeto educacional, inicialmente voltado às séries iniciais, para crianças, adolescentes e adultos analfabetos, como superação daquela escola rural. Amplia-se esta iniciativa com a participação dos movimentos integrantes da Via Campesina-Brasil e da CONTAG, constituintes do Movimento Camponês (RIBEIRO, 2011, p. 25)

Com efeito, o papel da escola como mediação no processo de dominação da classe burguesa é revisto pelos movimentos sociais. Subvertendo o caráter alijante dos conteúdos e formas, os próprios trabalhadores, descobrem outras possibilidades no espaço escolar. De fato, a educação precisava cumprir sua função política, para Saviani "a função política da educação cumpre-se na medida em que ela se realiza como prática especificamente pedagógica" (SAVIANI, 2002, p. 90). Contrariamente ao projeto capitalista, a escola do/no campo é tomada pela factível leitura crítica do mundo e das coisas. Para Cassin (2014), traduzindo o pensamento gramsciniano, a escola seria sim, espaço de confirmação da própria luta de classes, apesar de saber-se que a escola pode estar coligada com o ideário que funda o sistema do capital.

A luta de classes, no interior das escolas, é dominantemente luta ideológica, a luta pela manutenção da ideologia hegemônica das classes dominantes e a luta de resistência à essa imposição e a busca da construção de uma nova hegemonia. A escola em seu papel de transmissora da cultura das classes dominantes se constitui em importante instrumento de construção e manutenção da hegemonia ideológica, através do ensino e de outras formas ideológicas no interior das mesmas (CASSIN, 2014, p. 18).

Ocorre, todavia, que no percurso histórico, alguns estudiosos vão afirmar que a escola é o aparelho de disseminação e manutenção das ideologias vigentes, sobretudo é algo passivo, de dominação, ou seja, "a reprodução das condições de produção" (ALTHUSSER, 1985, p. 53) ainda afirma que; 


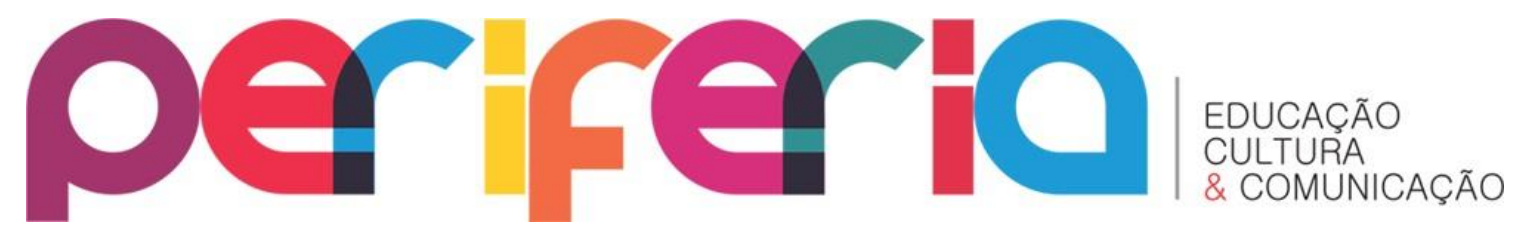

ISSN:1984-9540

DOI: $10.12957 /$ periferia. 2021.55083

A escola (...) ensina o "know how", mas sob formas que asseguram a submissão à ideologia dominante ou o domínio de sua "prática". Todos os agentes da produção, da exploração e da repressão, sem falar dos "profissionais da ideologia" (MARX) devem de uma forma ou de outra estar "imbuídos" desta ideologia para desempenhar "conscienciosamente" suas tarefas, seja a de explorados (os operários), seja a de exploradores (capitalistas), seja a de auxiliares na exploração (os quadros), seja a de grandes sacerdotes da ideologia dominante (seus funcionários) etc. (ALTHUSSER, 1985, p. 58 - 59).

Contudo, também vão surgir outros estudos contrários que irão subsidiar a luta dos trabalhadores pela escola que responda conforme a produção e reprodução da materialidade. Na escola como espaço de disputa reside as chances do embate reverso, muito embora tenhamos tendências legitimando modos organizativos da sociedade nos moldes burgueses, sabemos que existem insurgências opostas, ao mesmo tempo também sabemos que muitas vezes, as tendências de caráter opositor são cooptadas pelo capital, tão grande é seu poder.

Todavia, Saviani (2013) diz que é preciso observar que as tendências crítico-reprodutivistas, por exemplo, embora com limites, surgindo no bojo do movimento estudantil de 1968, sendo até certo ponto cooptadas pelo sistema, cumpriram seu papel de abrir caminhos para visão crítica no que tange ao papel da escolarização. Saviani afirma que "essa visão crítico-reprodutivista desempenhou um papel importante em nosso país, porque de alguma forma impulsionou a crítica ao regime autoritário desse regime, a pedagogia tecnicista" (SAVIANI, 2013, p. 58), ainda “de certa forma, essas teorias alimentaram reflexões e análises daqueles que em nosso país se colocavam-na oposição à pedagogia oficial e à política educacional dominante” (SAVIANI, 2013, p. 58).

$\mathrm{Na}$ construção dos conceitos aqui observados um aspecto latente está na percepção de que é inegável notar a escolarização na contribuição do controle e manutenção de classes, entretanto, também é factível que essa mesma escola não é um espaço cristalizado. A escola é feita por gentes, seres humanos mutáveis, mutantes de si e de seu contexto, e, nesse aspecto a escola porque 


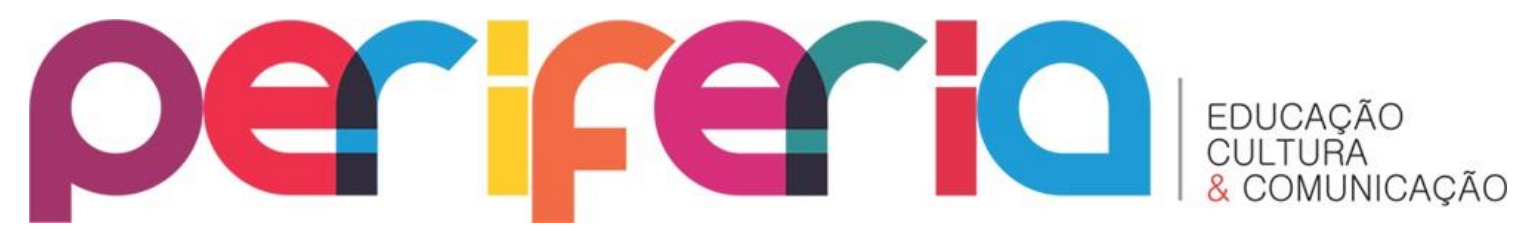

ISSN:1984-9540

DOI: $10.12957 /$ periferia.2021.55083

feita por sujeitos pensantes pede outra configuração, uma contra hegemonia construída pelos trabalhadores.

Toda hegemonia sugere uma contra-hegemonia devido ao movimento contraditório da realidade, como tal as próprias leis que subsidiam normativas escolares coercitivas são de tempos em tempos transformadas conforme o contexto Histórico, e, esse efeito vem da existência dos sujeitos. A exemplo, a primeira Lei de Diretrizes e Bases da Educação 4.024 de 1961 (LDB) traz nos artigos 31, 32 e 47 parâmetros de atendimento aos processos de escolarização. Todavia, sabemos que de certa forma a lei diz o que o Estado define, como tal, obviamente os sujeitos envolvidos e diretamente impactados não foram ouvidos nessa elaboração.

Para Marx "os homens fazem a sua própria história, contudo, não a fazem de livre e espontânea vontade, pois não são eles quem escolhem as circunstâncias sob as quais ela é feita, mas estas lhes foram transmitidas assim como se encontram" (MARX, 2011, p. 25) mas, essas condições historicamente postas vão requerer dos trabalhadores algum tipo de reação.

Desse modo, as leis educacionais são elaboradas para parametrizar normativas na educação nacional e segundo Saviani (2001) esse fato ocorre na perspectiva de implantação de um sistema nacional de educação. Esse sistema deveria atuar como instrumento orientador para democratização, no entanto, contraditoriamente o que se percebe é a perpetuação das ideologias da hegemonia política vigente cujo teor é classista, e, atua sempre no favorecimento hegemônico dos ricos.

Sobre a hegemonia social para Pronko e Fontes significa que:

O conceito apreende a dinâmica das lutas de classes sob a dominação burguesa explicando a produção da conformidade social por meio da organização e atuação da sociedade civil, voltada para o convencimento, ao lado da persistência das formas coercitivas do estado burguês (PRONKO \& FONTES, 2012, p. 391).

Nesse sentido, a elaboração de um conceito identitário na educação rural estaria respondendo ao que as leis propunham ou estariam propondo perspectivas para as leis? Sendo antecedente da lei, segundo Ribeiro (2012), o ruralismo pedagógico vem tentar responder a demanda anunciada no processo comparativo 


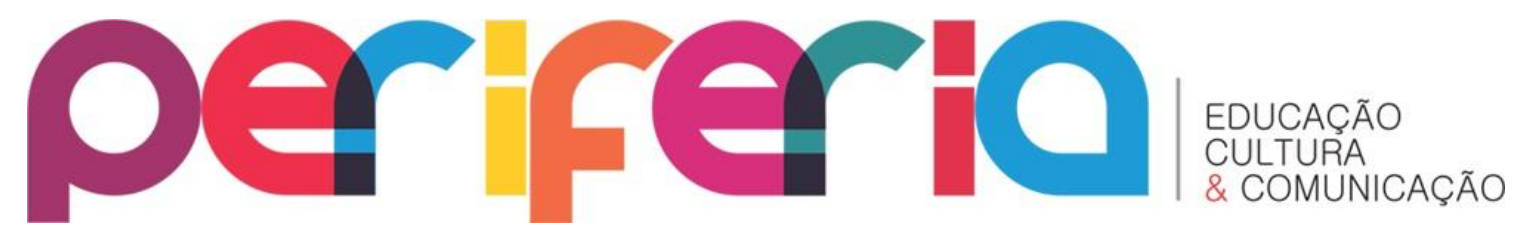

ISSN:1984-9540

DOI: $10.12957 /$ periferia. 2021.55083

dos resultados da formação entre urbano e rural. É claro que isso fomenta a visão binômica entre rural e urbano, para Ribeiro:

O fracasso da educação rural era comprovado pela existência de um grande contingente de analfabetos. Assim, o ruralismo pedagógico contrapunha-se à escola literária, de orientação urbana, que parecia contribuir para o desenraizamento do camponês, e, com isso, acompanhava as críticas do escolanovismo dirigidas à transmissão e à memorização de conhecimentos da realidade brasileira (RIBEIRO, 2012, p. 298).

Fato é que movidos pela desafiante realidade, os movimentos sociais no campo e intelectuais engajados e unidos entre parcerias, nos anos 1980 e 1990 vão se mobilizar e consolidar o conceito de "Educação do Campo". Sua centralidade naquele momento se fazia na urgência por políticas públicas referendadas no aspecto da especificidade das realidades na área rural (MOLINA, 2006). Como resultante, esse conceito cunhado pelo movimento é incorporado aos documentos oficiais tais como as Diretrizes Operacionais para a Educação Básica do Campo (BRASIL, 2002). Molina (2006) destaca que:

A especificidade da Educação do Campo, em relação a outros diálogos sobre educação deve-se ao fato de sua permanente associação com as questões do desenvolvimento e do território no qual ela se enraíza. A afirmação de que só há sentido no debate sobre Educação do Campo como parte de uma reflexão maior sobre a construção de um Projeto de Nação, popular e revolucionário, é o chão inicial capaz de garantir o consenso dos que se reúnem em torno desta bandeira (MOLINA, 2006, p.10).

Tal proposta situa a escola enquanto espaço de transformação social, de modo que, os conteúdos deviam estar centrados nos problemas sociais em cada comunidade. Os conhecimentos, os saberes tradicionais são valorizados diante de toda sua historicidade. A materialização da organização pedagógica inclui saberes e práticas atentas às particularidades dos sujeitos. A base epistemológica nessa proposta pedagógica se funda então na Pedagogia do Movimento conforme Arroyo (2008), Caldart (2012), Molina (2006), no Pensamento Pedagógico Socialista conforme Manacorda (2007), Pistrak (1981), Marx e Engels (2009), na Pedagogia libertadora conforme Paulo Freire (1987) entre outros teóricos considerados corolários nesse viés. 

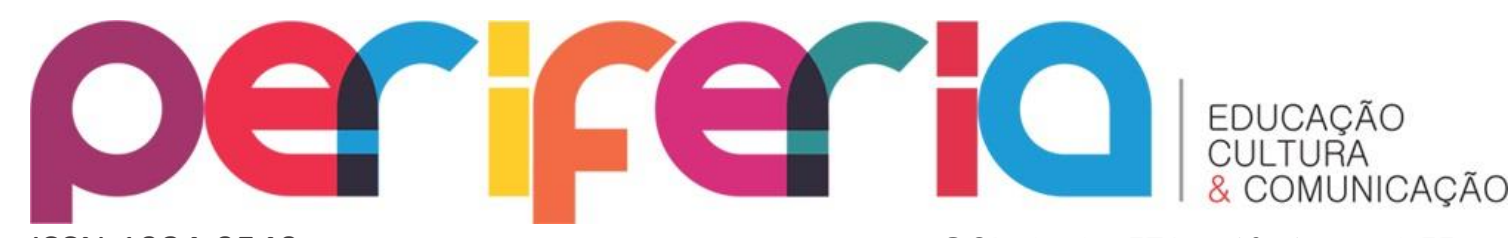

ISSN:1984-9540

DOI: $10.12957 /$ periferia. 2021.55083

O conceito de Educação do Campo vem defender processos formativos ligados de modo orgânico, produção da vida e a própria produção de bens, direito à terra para quem nela vive, contém forte discussão marxista e agrega certo pensamento mais eclético no sentido dessa organicidade epistêmica. De fato, toma materialidade no Movimento dos Trabalhadores Rurais Sem Terra e simboliza o levante organizado dos trabalhadores e intelectuais em luta e resistência pelas escolas nas comunidades, com currículos pensados com participação coletivizada e contextualizada (CALDART, 2012).

Segundo Molina e Azevedo de Jesus (2004, p. 8) "a identidade dessa educação a partir de seus sujeitos, da cultura, do trabalho, das lutas sociais e modos de vida dos camponeses, formam um conjunto de condições que não se limitam à escola, mas dela também se alimenta pela sua "vocação" universal de ajudar no processo de humanização". A identidade nesse modo de educar tem a vivencia humana enquanto mediação entre o ser social e a construção da consciência social (CALDART, 2012). Corroborando na ideia do movimento, Ribeiro (2012) em afirmar que "o trabalho produtivo articulado à unidade familiar que se envolve com este trabalho assume papel essencial no processo educativo de ingresso e participação ativa do camponês no corpo social” (2012, p. 296).

Caldart (2011) afirma que a Educação do Campo traz características próprias em que "a nova escola deve se abrir para a vida, incluindo sua articulação com outras formas sociais formativo-educativas tão importantes como a própria educação escolar" (CALDART, 2011, p. 152), e, "a concepção de escola do campo nasce e se desenvolve no bojo do movimento da Educação do Campo, a partir das experiências de formação humana desenvolvidas no contexto de luta dos movimentos sociais camponeses por terra e educação." (MOLINA e SÁ, 2012, p. 326). Ainda que:

A concepção de escola do campo se insere também na perspectiva gramsciniana da Escola Unitária, no sentido de desenvolver estratégias epistemológicas e pedagógicas que materializem o projeto marxiano da formação humanista omnilateral, com sua base unitária integradora entre trabalho, ciência e cultura, tendo em vista a formação dos intelectuais da classe trabalhadora" (MOLINA e SÁ, 2012, p. 327). 


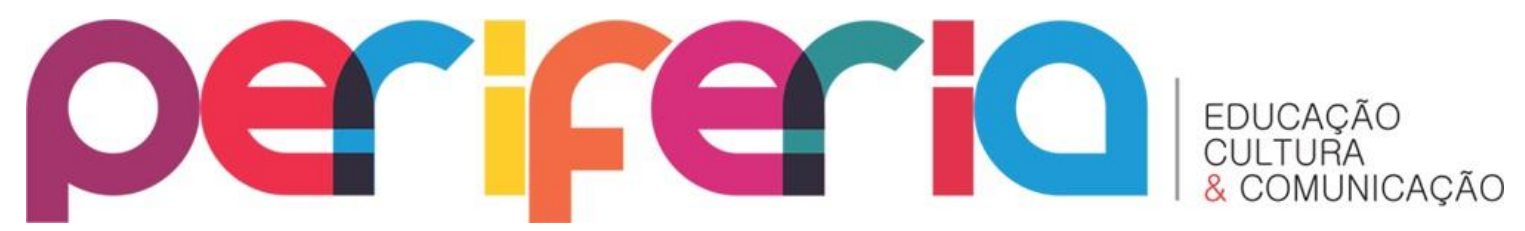

ISSN:1984-9540

DOI: $10.12957 /$ periferia.2021.55083

Nesse sentido, a elaboração do conceito Educação no Campo de acordo com as leituras realizadas, surge como contraponto fortemente apoiado na perspectiva traçada pela Pedagogia Histórico-Crítica conforme elaborada nos anos 1980 por Demerval Saviani (2013). Baseada em estudos e pesquisas na área rural esse conceito vem capitaneado pelo Grupo de Estudo e Pesquisa sobre Educação no Campo, e, segundo Basso e Bezerra Neto (2017) significa a luta em defesa da educação escolar na área rural como "aquela que visa o direito de todos os trabalhadores ao acesso aos conhecimentos historicamente construídos, sejam eles do campo ou da cidade" (2017, p. 189).

0 coletivo traz justificativas contrárias em relação ao processo de organização pedagógica em que se prioriza na escolarização rural questões centradas nas especificidades do meio rural. Tece então seus argumentos na defesa de um processo de escolarização que tenha centralidade no conhecimento clássico das ciências, na formação sistematizada para os trabalhadores e seus filhos de modo a qualificar suas potencialidades técnico, cientifica e humanas.

Defende-se a formação para enfrentar os desafios da sociedade movida pelo capital seja no campo ou cidade, na verdade busca e se deseja desmistificar o estereótipo histórico legado ao sujeito e realidade do campo como inferiores diante dos padrões traçados para o perfil da realidade e do sujeito urbano. Para Bezerra Neto e Bezerra (2011) a crítica ao modo de organização da escolarização segundo o Movimento Por Uma Educação do Campo é que:

Por adotar uma postura de cunho idealista, o "Movimento por uma Educação do Campo" apresenta um viés fenomênico na interpretação da realidade brasileira e do mundo, analisando-a de forma superficial. Em decorrência disso, coloca a organização escolar, do ponto de vista de suas propostas pedagógicas, no âmbito de pedagogias que se enquadram nos perfis destas correntes filosóficas, aproximando a educação do campo dos pressupostos da pós-modernidade. Neste sentido, estão ligadas a propostas de educação que supervalorizam a prática e o cotidiano, derivadas da concepção de que é pela cultura que se formam os indivíduos (BEZERRA NETO e BEZERRA, 2011, p. 3).

Desse modo, os estudiosos nessa perspectiva situam aspectos dilacerantes relativos as possibilidades de transformação da realidade social no 


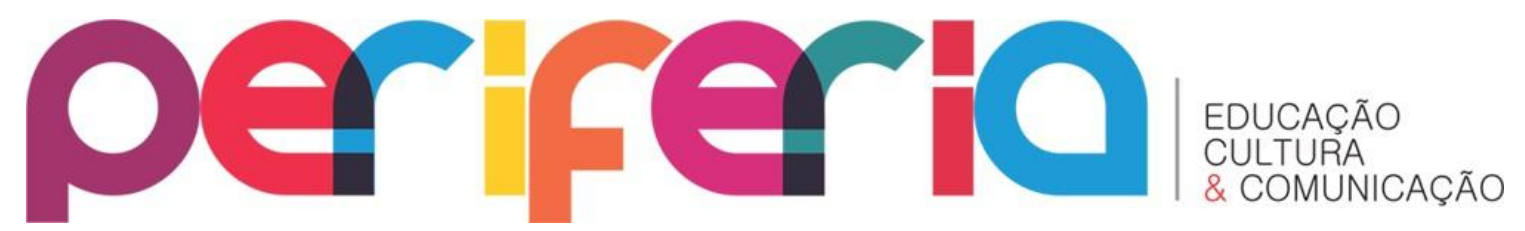

ISSN:1984-9540

DOI: $10.12957 /$ periferia. 2021.55083

campo, caso não se tenha em vista o aporte de uma pedagogia que possua em sua matriz o materialismo histórico dialético, ou seja, a práxis educativa. Como tal afirmam que:

Outro aspecto importante para a compreensão da escola do campo é o conceito de práxis, uma categoria importante para o entendimento das epistemologias dos projetos de educação do campo. Para o marxismo, mais do que interpretar a realidade, interessa transformá-la, o que coloca a prática como o início da ciência social. Para alterá-la é necessário entendê-la. Neste sentido, o entendimento da realidade não pode ser feito sem a mediação de conhecimentos teóricos, entendidos estes enquanto abstrações realizadas a partir de constantes e infinitas aproximações entre a realidade empírica e o conjunto de conhecimentos sobre a realidade produzidos pela humanidade ((BEZERRA NETO e BEZERRA, 2011, p. 4).

Segundo Saviani o "clássico na escola é a transmissão-assimilação do saber sistematizado. Este é o fim a atingir" (SAVIANI, 2013 p. 17) então, ao situar a centralidade da formação escolar nas especificidades locais da área rural coloca-se em perigo a formação do próprio sujeito do campo no campo. Nega-se ao sujeito campesino, ribeirinho, caiçara, etc. o seu empoderamento cientifico e técnico de tal feita que se nega as armas necessárias na luta contra o poder opressor.

Saviani chama nossa atenção para as diferenciações nessa concepção que é crítica essencialmente, dialética, e prima pela transformação social dos sujeitos de direito a partir da apropriação dos saberes seculares, além dos saberes locais. Para ele "diferencia-se da visão critico-reprodutivista, uma vez que procura articular um tipo de orientação pedagógica que seja crítica sem ser reprodutivista” (SAVIANI, 2013, p. 57).

No entanto, em relação as tendências pedagógicas críticas, Saviani destaca a importância da visão crítico-reprodutivista no momento de enfrentamento à pedagogia tecnicista que vigorava durante o regime político autoritário e fascista dos anos 1960 e 1970 no Brasil, todavia, afirma também o caráter crítico revolucionário de uma pedagogia que instrumentalize os trabalhadores na luta por sua libertação diante das opressões.

Para Saviani: 


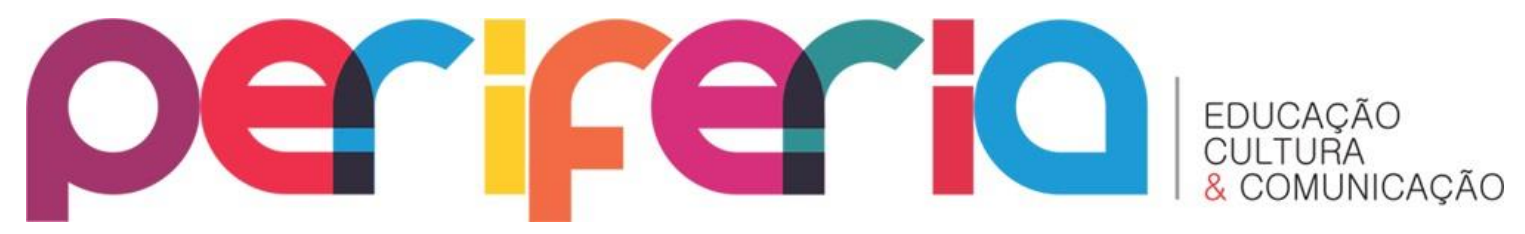

ISSN:1984-9540

DOI: $10.12957 /$ periferia. 2021.55083

Uma pedagogia revolucionária centra-se, pois, na igualdade essencial entre os homens. Entende, porém, a igualdade em termos reais e não apenas formais. Busca converter-se, articulando-se com as forças emergentes da sociedade igualitária. Para isso, a pedagogia revolucionária, longe de secundarizar os conhecimentos descuidando de sua transmissão, considera a difusão de conteúdos, vivos e atualizados, uma das tarefas primordiais do processo educativo em geral e da escola em particular (SAVIANI, 2002, p. 65).

É preciso que a escola no campo atue para o fortalecimento da própria classe trabalhadora e possibilite o acesso desses sujeitos aos conhecimentos científicos, os mesmos conhecimentos que são apropriados pela classe dominante. É necessário construir uma escola que capacite os trabalhadores e seus filhos em igual paridade intelectual/técnica com aqueles que compõem a classe que os oprime.

Nesse entender, a escola ao agir no modo contrário distancia os trabalhadores na disputa alargando e mantendo o fosso social, sendo essa a miséria que alimenta o próprio capital. A educação no campo exalta a práxis corroborada na Pedagogia Histórico-Crítica iniciando o processo na prática social voltando a ela como resultante da transformação causada pelo acesso ao conhecimento (SAVIANI, 2013).

Para Bezerra Neto significa que:

Outro aspecto importante para a compreensão da escola do campo é o conceito de práxis, uma categoria importante para o entendimento das epistemologias dos projetos de educação do campo. Para o marxismo, mais que interpretar a realidade, interessa transformá-la, o que coloca a prática, como o início da ciência social. Para alterá-la, entretanto, é necessário entendela (BEZERRA NETO, 2010, p. 4).

O pensamento marxista é o norte na organização da "Educação no Campo" e seus corolários vão primando por elementos que no fazer escolar situam o trabalho e a existência histórica/social dos trabalhadores como eixos. Nessa relação objetiva e subjetiva entre seres e natureza, "ao produzirem os seus meios de subsistência, os homens produzem indiretamente sua própria vida material" (MARX, 2009, p. 24). 


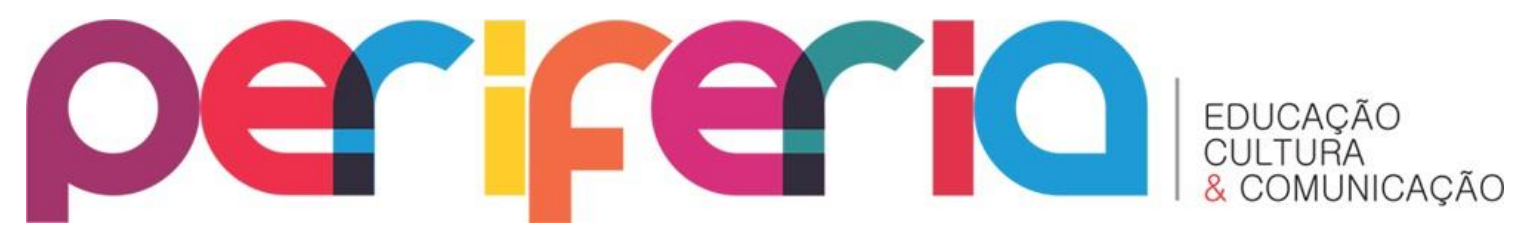

ISSN:1984-9540

DOI: $10.12957 /$ periferia. 2021.55083

A formação do trabalhador deve ser aquela que permita para ele ea compreensão da realidade concreta, em toda sua totalidade, em seus determinantes, mas não como fato dado, mas, um fato a ser transformado. Os seres também não são objetos dados, são seres em permanente transformação e segundo Marx significa que:

Não se parte daquilo que os homens dizem, imaginam ou se representam, e também não dos homens narrados, pensados, imaginados, representados, para daí se chegar aos homens em carne e osso; parte-se dos homens realmente ativos e, com base no seu processo real da vida, apresenta-se também o desenvolvimento dos reflexos e ecos ideológicos desse processo de vida (2009, p. 31).

O conceito de Educação no Campo segundo Bezerra Neto (2010) apresenta argumentos fundados na realidade da luta de classes, na compreensão sobre as relações históricas, a produção da própria vida, o horizonte é a emancipação humana. Segundo Marx e Engels "não é a consciência que determina a vida, é a vida que determina a consciência" (2009, p. 32), o conhecimento sobre a existência, sobre a real concretude não é uma epifania, um sonho de difícil realização como sobrenatural.

Na obra "Ideologia alemã" afirmam que "o ser dos homens é o seu processo real de vida" (MARX e ENGELS, 2009, p. 31), de modo que a proposta do grupo de pesquisa caminha nessa posição, considerando a escolarização momento de luta real, o fazer pedagógico é então arma contra ideologias opressoras, de modo que o saber organicamente sistematizado deve suprir tal intenção.

O levante revolucionário contra a situação opressora no âmbito da pesquisa e do estudo vai sendo consolidado na construção dos próprios conceitos. No empenho teórico dos grupos reside entre divergências e convergências, elementos práticos advindos das experiências conjuntas, das margens em que cada um se coloca, e, também do encontro inevitável no rebojo das ondas violentas de ataques aos processos educacionais pelo sistema capitalista, em especial pelo governo bolsonarista.

Nas aparências subjetivas e objetivas os caminhos da concórdia conceitual em
permanente transformação Periferia, v. 13, n. 1, p. 101-123, jan./abr. 2021 


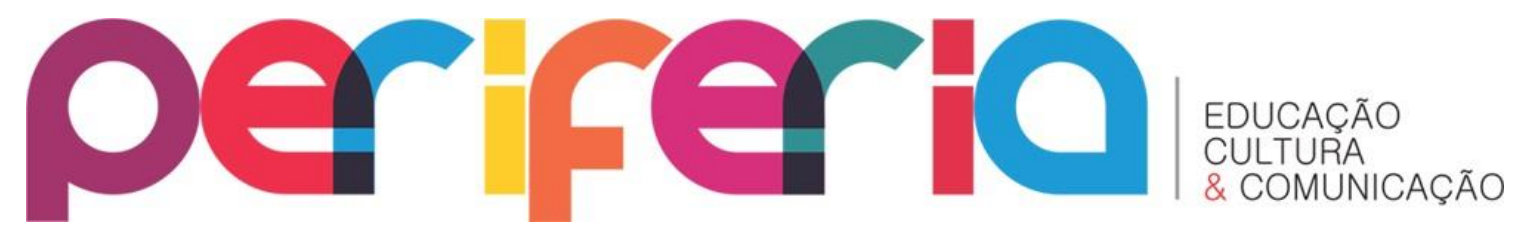

ISSN:1984-9540

DOI: $10.12957 /$ periferia. 2021.55083

Assumimos a posição em que segundo lanni "o processo de pensar, a reflexão é uma reflexão sempre crítica, na medida em que ela não só duvida do que vê, duvida do que está explicado, mas, crítica no sentido que ela tem a audácia, a arrogância, de participar da constituição do objeto" (IANNI, 2011, p. 404), quer dizer que nosso compromisso se faz na ânsia por ampliar a reflexão relativa à Educação do/no Campo e seus entremeios.

lanni (2011) confirma que "essa discussão sobre o compromisso do pensamento com o pensado, da teoria e da prática é uma discussão fundamental. No caso da reflexão dialética, ela é assumida como algo essencial da explicação. 0 pensamento, ao mesmo tempo em que se constitui, se desenvolve, se articula entra na constituição do real” (IANNI, 2011, p. 409) assim nosso fazer pensado lógico-conceitual se consolida.

Dito isso, diante do que se coloca como fundamental na reflexiva percepção relativa aos fazimentos teóricos/práticos dos coletivos acima citados, na acepção das suas interioridades, o primeiro elemento comum encontrado é a dimensão política. A dimensão política situa a educação como chão de disputa permanente, disputa essa travada entre as classes que historicamente formam a sociedade. Para Saviani a dimensão política na educação "a importância política da educação reside na sua função de socialização do conhecimento. É realizandose na especificidade que the é própria que a educação cumpre sua função política" (SAVIANI, 2002, p. 88)

$O$ processo de organizar organicamente uma unidade em meio a tantas diversidades traz desafios constantes, seja aos processos educativos ou de produção de uma concepção que o represente integralmente. A antagonia teórica que aparta os iguais na construção do pensamento epistêmico outro momento pode unir em certa medida os antagônicos. Nisso, ao refletir sobre o pensamento pedagógico de base socialista que ancora os dois modos de proposta para organizar a educação na área rural, nota-se que apesar do tom eclético dado por um em detrimento da visão radical e de conjunto do outro, reside nos mesmos a dimensão política e a necessária revolução na formação de quadros via escolarização. 


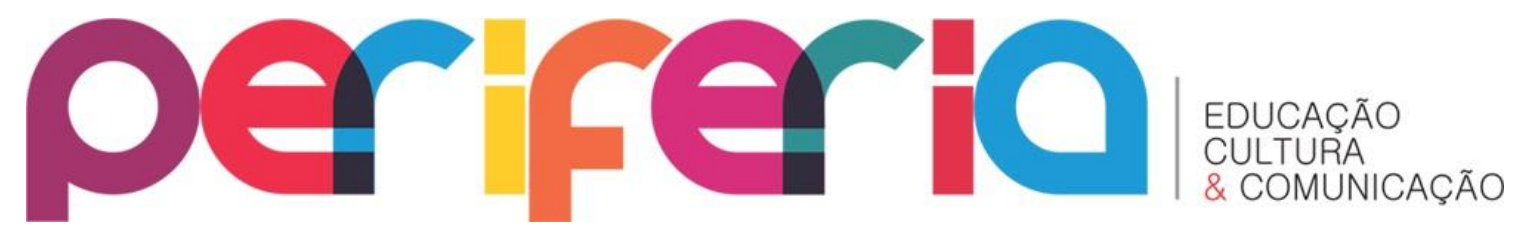

ISSN:1984-9540

DOI: $10.12957 /$ periferia. 2021.55083

$\mathrm{O}$ fato é que a resistência contra a necropolítica imposta por setores da classe dominante brasileira, a partir da metade da segunda década do século XXI, constitui elemento óbvio em ambos os grupos aqui destacados. Essa é uma aproximação explicativa até certo ponto abstrata do ponto de vista de quem está de fora dessas relações coletivas, tentar explicar a essência de cada grupo é presunção improvável. Ademais, a identidade objetiva e subjetiva de cada grupo, por estar do mesmo modo em plena construção dialética, evidencia a incompleta generalidade.

Longe de alinhar conclusões, ou de tecer arremate epistemológico final conceitual, costuramos aproximações diante das teorizações acessiveis sobre o tema discutido, e diante disso, pontuamos elementos de ancoragem presente nos dois coletivos. Deixaremos os aspectos de conflito antagônico conceitual que possam existir ou coexistir para discutir em outras abordagens.

Diante das expectativas de compreender os elementos que poderiam unir as duas concepções, ousamos evidenciar abaixo alguns elementos advindos de nossa observação que podem expressar a unidade de luta no presente desafio coletivo:

a) Primeiro é evidente o engajamento na defesa dos processos educacionais dos trabalhadores residentes na área rural a partir do trabalho;

b) Segundo: o entendimento da educação escolar como inegavelmente constitutiva na promoção e alcance de direitos negados aos que não conseguem acessar o processo educativo;

c) Terceiro: a base no pensamento pedagógico socialista e seus corolários como norteamento subjetivo e objetivo na construção epistêmica;

d) Quarto: a defesa da escola no campo, o não fechamento das escolas como política pública inegável a esses trabalhadores;

e) Quinto: a defesa da inserção da educação na área rural na pauta das políticas educacionais;

f) Sexto: a valorização da vida e existência digna dos trabalhadores residentes na área rural;

g) Sétimo: a luta por uma sociedade de direitos para todos seus cidadãos; 


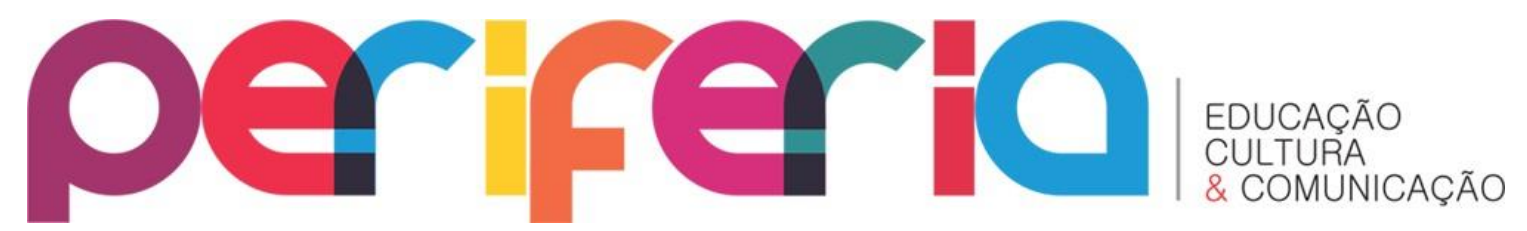

ISSN:1984-9540

DOI: $10.12957 /$ periferia. 2021.55083

h) Oitavo: a luta pela escolarização ampla e irrestrita para todos os trabalhadores rurais e seus descendentes;

i) Nono: a pesquisa e produção de referenciais e inserção destes nas discussões acadêmicas nacionais e internacionais;

j) Décimo: o compromisso político com a humanização e valoração da classe trabalhadora na área rural.

Tais indicadores nos fazem crer que esses aspectos necessitam estar presentes contidos na identidade da educação na área rural, seja na região norte, nordeste, sul sudeste, centro oeste do país. Pensar qual a escola que queremos para área rural, qual o currículo, qual o modo de gestão, também como a universidade poderá contribuir nessa construção sem alijar os sujeitos envolvidos na escola, parece óbvio. Essa obviedade está como os estudos e pesquisas aproximados do chão da escola, dos movimentos sociais podendo juntos formar um conjunto radical e lógico que incorpore o conceito "do" e "no" campo.

Dito isso, importa ressaltar que aqui temos limitações, e que, fica claro em ambos os desafios de conceituação a palavra "campo" representa para além do espaço geográfico, territórios e territorialidades. Para além disso, necessariamente "uma pedagogia revolucionária centra-se, pois, na igualdade essencial entre os homens [...] porém, a igualdade em termos reais e não apenas formais" (SAVIANI, 2002, p. 65) portanto, seria essa necessidade a ser suprida de modo que o conceito representativo dessa ação, ou seja, o conceito da educação no meio rural, deve essencialmente incorporar tanto conteúdos quanto formas para efetivar tal premissa.

Com a existência de forças opressoras, mesmo sofrendo determinações a educação permite subversão e as condições concretas não nos esterilizam nessa disputa. Claro também fica que as bases socialistas em ambos os coletivos, são ímpetos no movimento de transformação que os conduz.

\section{Considerações finais}

Diante do exposto, longe de conclusões sobre o fato, afirma-se a intencionalidade contida nas duas conceituações como formas de resistir aos 


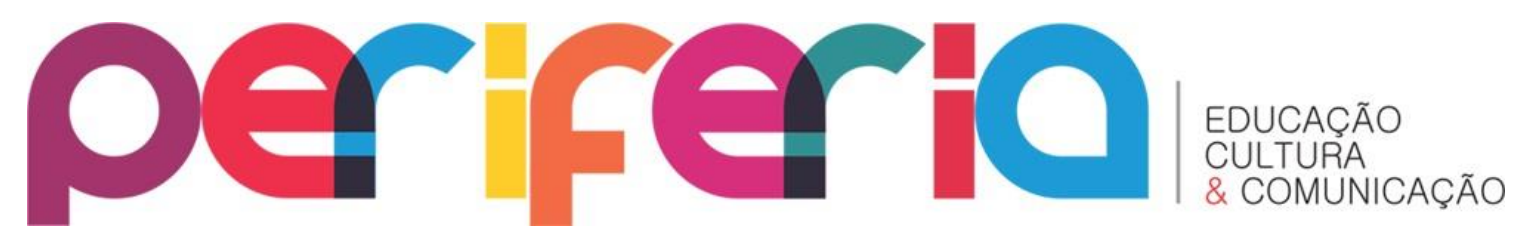

ISSN:1984-9540

DOI: $10.12957 /$ periferia.2021.55083

desafios postos. Estando na academia ou nas comunidades rurais, enquanto trabalhadores, é preciso descortinar realidades veladas pelo sistema opressor, juntar-se, unir os coletivos. Embora seja inquestionável que as subjetividades condicionem o modo de ver e perceber em cada um, e isso gera contradições, a unidade é desejável para a luta.

É importante perceber que precisamos responder às questões como, "trata-se de integrar o homem do campo à economia de mercado, tornando-a eficiente? Deve-se educar o homem para a sua permanência no campo? Estes são alguns dos dilemas das propostas educacionais para o campo" (BEZERRA NETO e BEZERRA, 2011, p. 3). Os enfrentamentos requerem a unidade da classe trabalhadora, e, seguiremos na perspectiva do eco atemporal da afirmação de Marx e Engels quando dizem "proletários uni-vos" (MARX e ENGELS, 2014, p. 192) nas Amazônias, Caatinga, Cerrado, Mata Atlântica, Pampa e Pantanal.

\section{Referências}

ALTHUSSER, Louis. Aparelhos Ideológicos de Estado: nota sobre os aparelhos ideológicos de Estado. Tradução de Walter José Evangelista e Maria Laura viveiros de Castro. Rio de Janeiro. Ed. Graal, 1985.

ARROYO, Miguel. et al.. Por uma educação do campo. Petrópolis, RJ. Ed. Vozes, 2008.

ARROYO, Miguel. Trabalho, educação e teoria pedagógica. In: FRIGOTO, Gaudêncio. (org.) Educação e crise do trabalho: perspectivas de final de século. Petrópolis. Ed. Vozes, 1998.

BEZERRA NETO, Luiz. Educação do campo ou educação no campo? HISTEDBR Online, $\mathrm{n}^{\circ}$ 38, p. 150-168, 2010.

BEZERRA NETO, Luiz. Sem Terra aprende e ensina: estudo sobre as práticas do movimento dos trabalhadores rurais. Campinas. SP. Ed. Autores Associados, 1999.

BEZERRA NETO, Luiz; BASSO, Jaqueline Daniela. Educação do/no campo/rural: o que tem sido produzido nos programas de pós-graduação? In: Trabalho $e$ educação: estudos sobre o rural brasileiro. SANTOS NETO, Jose Leite; BEZERRA NETO, Luiz; BEZERRA, Maria Cristina Santos (org.). São Carlos: Ed. Pedro \& João. 2017. 


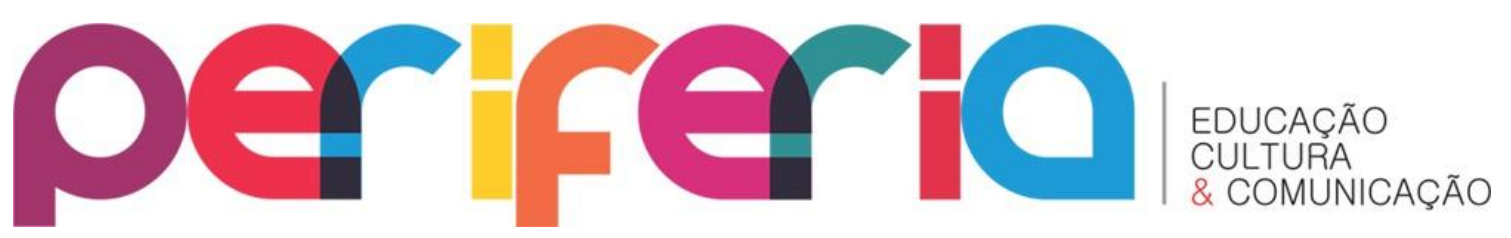

ISSN:1984-9540

DOI: $10.12957 /$ periferia. 2021.55083

BEZERRA NETO, Luiz; SANTOS NETO, Jose Leite; BEZERRA Maria Cristina Santos

Trabalho e educação: estudos sobre o rural brasileiro. São Carlos: Pedro \& João Editores, 2017.

BEZERRA NETO, Luiz; BEZERRA, Maria Cristina Santos. Educação no Campo: referenciais teóricos em discussão. Revista EXITUS, v. 01, n 01, p. 01-18, jul./dez 2011.

BRASIL. Ministério da Educação. Conselho Nacional de Educação. Diretrizes Operacionais para a Educação Básica nas Escolas do Campo. Brasília, DF, 2002.

BRASIL, Ministério da Educação. Secretaria de Educação Continuada, Alfabetização, Diversidade e Inclusão - SECADI. Educação do Campo: marcos normativos/Secretaria de Educação Continuada, Alfabetização, Diversidade e Inclusão - Brasília: SECADI, 2012.

CALDART, Roseli Salete. A escola do campo em movimento. Revista Currículo sem Fronteiras. V. 3, n. 1, p. 60-81, 2003.

CALDART, Roseli Salete. A educação do campo e a perspectiva de transformação da forma escolar.IN.: MUNARIM, A. BELTRAME, S. CONDE, S. F. PEIXER, Z. I. Educação do Campo: reflexões e perspectivas. $2^{\mathrm{a}}$ Ed. Florianópolis: Editora Insular, 2011, p. 145-187.

CALDART, Roseli Salete. Pedagogia do Movimento Sem Terra. 4. Ed. São Paulo. Expressão Popular, 2012.

CASSIN, Marcos. Louis Althusser: Aparelhos Ideológicos de Estado e a Escola. Disponível em In: https://marxismo21.org/wp-content/uploads/2014/08/LouisAlthusser-Aparelhos-Ideologicos-e-a-Escola-M-Cassin.pdf Acesso em 03/12/19.

ENGELS, Friedrich. A situação da classe trabalhadora na Inglaterra. São Paulo. Boitempo, 2010.

FREIRE, Paulo. Pedagogia do Oprimido. Rio de Janeiro. Paz e Terra, 1987.

GRAMSCI, Antônio. Cadernos do cárcere. Rio de Janeiro. Civilização Brasileira, 2001.

IANNI, Otaviano. A construção da categoria. Revista HISTEDBR On-line, v. 11, n. 41e, p. 397-416, abr 2011.

MANACORDA, Mario Alighiero. Max e a pedagogia moderna. Ed. Alínea. SP, 2007.

MARX, Karl; ENGELS, Friedrich. O manifesto do partido comunista. Tradução Luciano Cavini Martorano. São Paulo. Martin Clarete, 2014. 


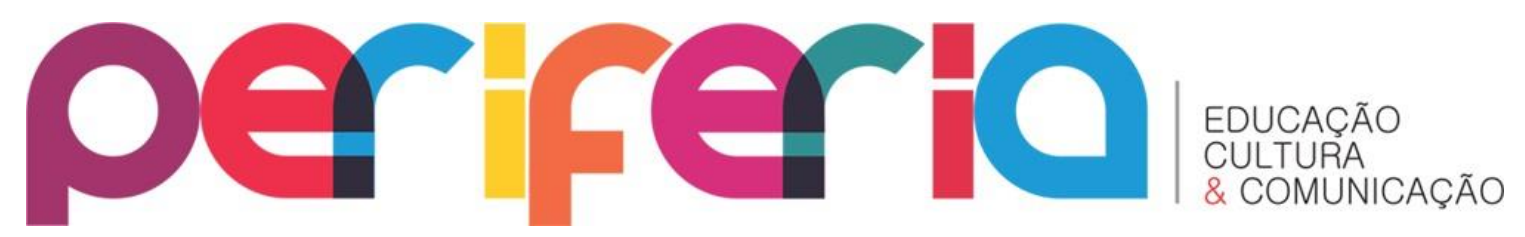

ISSN:1984-9540

DOI: $10.12957 /$ periferia. 2021.55083 MARX, Karl; ENGELS, Friedrich. A ideologia alemã. Tradução de Álvaro Pina. $1^{\circ}$ ed. São Paulo. Expressão Popular, 2009.

MEZÁROS, Estevam. A teoria da alienação em Marx. Tradução de Isa Tavares. São Paulo. Boitempo, 2006.

MOLINA, Mônica Castagna. Ministério do Desenvolvimento Agrário. Educação do Campo e Pesquisa: questões para reflexão. Brasília: Ministério do Desenvolvimento Agrário 2006.

MOLINA, Mônica Castagna; AZEVEDO DE JESUS, S. M. S. (org.). Contribuições de um projeto de educação do campo. Brasília. DF. Articulação Nacional por uma educação do campo, 2004.

MOLINA, Mônica Castagna; SÁ, Lais Mourão. Escola do Campo. In: Dicionário da Educação do Campo. CALDART, Roseli Salete; PEREIRA, Isabel Brasil;

ALENTEJANO, Paulo; FRIGOTTO, Gaudêncio. Rio de Janeiro. Expressão Popular, 2012.

PISTRAK, Moisey Mikhailovich. Fundamentos da escola do trabalho. Tradução de Mauricio Trandeberg. São Paulo. Brasiliense, 1981.

PRONKO, Marcela; FONTES, Virginia. Hegemonia. In: Dicionário da Educação do Campo. CALDART, Roseli Salete; PEREIRA, Isabel Brasil; ALENTEJANO, Paulo. FRIGOTTO, Gaudêncio. Rio de Janeiro. Expressão Popular, 2012.

RIBEIRO, Marlene. Educação Rural. In: Dicionário da Educação do Campo.

CALDART, Roseli Salete; PEREIRA, Isabel Brasil; ALENTEJANO, Paulo; FRIGOTTO, Gaudêncio. Rio de Janeiro. Expressão Popular, 2012.

RIBEIRO, Marlene. Educação do Campo e Escola Ativa: contradições na política educacional no Brasil. Educação em revista, Marília, v.12, n.2, p. 23- 40, jul. dez, 2011.

SAVIANI, Demerval. Pedagogia Histórico-Crítica. Primeiras aproximações. Campinas. SP. Autores Associados, 2013.

SAVIANI, Demerval. Escola e Democracia: teorias da educação, curvatura da vara, onze teses sobre educação política. Campinas. SP. Autores Associados, 2002.

SCHAFF, Adam. História e verdade. São Paulo: Martins Fontes, 1995. 